\title{
In-your-face Watergate: neutralizing government lawbreaking and the war against white-collar crime
}

\author{
Henry N. Pontell ${ }^{1}$ (D) $\cdot$ Robert Tillman ${ }^{2} \cdot$ Adam Kavon Ghazi-Tehrani $^{3}$
}

Accepted: 11 February 2021/ Published online: 14 April 2021

(C) The Author(s), under exclusive licence to Springer Nature B.V. 2021

\begin{abstract}
Ample official evidence exists that the Trump administration was the most corrupt in modern American history. Donald Trump's overall pattern of behavior not only resembled, but amplified that of major white-collar criminals. This paper has two main foci. First, it argues that government criminality and corruption were facilitated by rationales and excuses that denied effective social condemnation of such acts. Second, it considers how these defenses were weaponized by the Trump administration as part of a much larger and more deliberate "war on white-collar crime" more generally. As a result, enormous efforts are necessary to restore and strengthen regulatory and enforcement regimes, and transcend deepened political cleavages on such matters. Through a new hybrid neutralization technique, normalization of condemning the condemners, Trump exacerbated existing political differences and influenced supporters to at once ignore government crime and corruption, and accept new moral narratives that flew in the face of substantial evidence of criminality.
\end{abstract}

Keywords White-collar crime $\cdot$ Neutralization $\cdot$ Corruption $\cdot$ Rule of law

Ample official evidence exists that the Trump administration was the most corrupt in modern American history. Since the inauguration itself, which is under investigation for various funding illegalities [1], it remains embroiled in a number of alleged

Henry N. Pontell

hpontell@jjay.cuny.edu

Robert Tillman

tillmanr@stjohns.edu

Adam Kavon Ghazi-Tehrani

aghazi@ua.edu

1 Department of Sociology, John Jay College of Criminal Justice, CUNY, New York, NY, USA

2 Department of Sociology, St. John's University, New York, NY, USA

3 Department of Criminology and Criminal Justice, University of Alabama, Tuscaloosa, AL, USA 
improprieties, some of which include involvement with foreign interference by Russia in the 2016 election [2], emoluments violations [3], family self-dealing while in office [4], extortion in Ukraine [5], withholding and unduly influencing vital information on a deadly pandemic, [6] obstruction of justice [7], fraudulent fund-raising efforts [8], election interference [9], prompting a seditious use of the judicial process in the wake of a losing reelection effort [10] and inciting a mob to storm the Capitol Building that resulted in multiple deaths and injuries [11].

The actions of the former president and those close to him have produced a virtual cottage industry of books and intense media scrutiny documenting aberrant behaviors and dangers to national security, and damage to major U.S. institutions including democracy itself $[6,12-16,17-27]$. Analyses focus on his penchant to cheat in all matters, including, business, marriage, and golf, psychological deficiencies, including narcissistic personality disorder, authoritarianism, and signs of dementia, and being a symptomatic expression of many Americans' frustration and anger, which has helped result in his cult-like influence over supporters. These descriptions capture elements of truth, but also neglect a crucial aspect of Donald Trump's overall pattern of behavior which not only resembles, but amplifies that of major white-collar criminals. This idea is supported by the fact that as of July 13, 2020, The Washington Post documented over 20,000 false or misleading statements uttered by Trump while in office [28].

A juxtaposition with Watergate, the darkest chapter in presidential history, seems appropriate given Trump's behavior, but even that comparison could be considered incorrect and unfair; to Watergate. Comedian John Oliver, labelled the 2016 Russian election meddling scandal and its attempted cover-up, "Stupid Watergate." More broadly, one commentator noted that comparisons are not warranted at all given the central nature of Trump's potential criminality before and after taking office:

It would be wrong to think about Trump's behavior as existing on the same spectrum as that of his post-Watergate predecessors. To see why, you have to first look back on the entire Trump presidency in a different way - one that sees his possibly criminal conduct not as a byproduct of the pursuit of a political agenda but as a central, self-perpetuating feature of his tenure. In this light, Trump's potential criminality becomes a kind of throughline, the dots that connect his life as a businessman to his entry into politics and then onward across his four years as president. One potentially illegal act led Trump to the next: from his lawbending moves as a businessman, to his questionable campaign-finance practices, to his willingness to interfere with investigations into his conduct, to his acts of public corruption and, finally, to the seemingly illegal abuse of the powers of his office in order to remain in office [29].

Given these characteristics of Trump's presidency, criminology naturally provides a salient, yet neglected lens for interpreting what appears to his detractors as blatant, "inyour-face" corruption and fraud among other aberrant behaviors by the former president and his close associates.

This paper has two main foci. First, it argues that government criminality and corruption are facilitated by rationales and excuses that deny effective social condemnation of such acts. In the case of Trump, these rationales became "normalized" through network media coverage and dissemination through social media, as new 
scandals diminished older ones by burying them in the news cycle. Both legal questions and the sheer number of alleged corrupt acts themselves resulted in attenuating the collective response that could be directed at each. Understanding this lack of effective condemnation is a major goal of the current analysis.

Second, it considers how these defenses were weaponized by the Trump administration as part of a much larger and deliberate "war on white-collar crime" more generally. Denying and excusing corrupt acts at the highest levels of government, transmits a strong message that less egregious acts by other powerful figures can be absolved as well, allowing them to be engaged in with impunity. Another integral part of the war involved the radical deregulatory policy fostered by the Administration which crippled the government's capacity to proactively police major white-collar and corporate crime [30].

Two conceptual caveats accompany the following analysis. First, it adopts the approach initially argued forcefully by Thorsten Sellin [31] that in studying crime, social scientists should not adhere to, or be limited by legal definitions appearing in penal codes. The law (as well as its enforcement) is the product of power, lobbying, whim and other idiosyncratic inputs that often lack logical coherence. That is, some harmful acts are never outlawed because those who commit them or contemplate doing so see to it that they are not. Strict adherence to legal definitions, according to Sellin, "violates a fundamental criterion of science," ([31], p. 31) in that the freedom to define specific characteristics and properties under study is confined. "White-collar crime" is not a legal term, although many laws are applied to specific forms of offending that could be included under this socially constructed label.

Second, and relatedly, the paper assumes a "populist" framework which examines white-collar criminality in relation to status, power, and social inequality, as opposed to a "patrician" view that offers a less politicized and more legal-technical perspective of such offending [32]. The latter is more restrictive to the study of deviance and crime as put forth by Sellin, and minimizes the phenomenon and impact of white-collar crime by considering only those cases that are legally adjudicated and found in official databases. The populist perspective is more expansive and better suited for understanding issues of power, respectability and privilege, all of which are, perhaps to the highest degree, integral to a U.S. presidency. Adopting this approach is thus better suited and less confining for social scientific analysis, as it avoids well-documented biases that feed into the content of the criminal law [33].

\section{All the President's Men, revisited}

The Watergate scandal, perhaps the darkest chapter in American presidential history, saw the resignation of President Richard Nixon and convictions of numerous associates, including close personal friend, Attorney General John Mitchell. One stark difference between that disgraceful episode and the Trump presidency is that the single White House cover-up of the Watergate burglary was determined at the end of congressional hearings with the disclosure of secret edited tapes. The Trump administration's multiple cover-ups occurred in public and in real time through vehement denials, pardon dangles, and other overbearingly defiant acts, including vilifying accusers, all in the face of damning material evidence. At both the initial stages and 
throughout the Special Prosecutor's investigation into Russian meddling in the 2016 election, Trump relentlessly decried it as a "witch hunt" [34]. A notable early response to his position was offered by former prosecutor and conservative Congressman Trey Gowdy, who presided over the controversial Benghazi Hearings in a Republicancontrolled Congress that were ultimately unsuccessful in tying Secretary of State Hillary Clinton to official wrongdoing. He appeared on Fox News offering the indignant president's attorney at the time, John Dowd, nothing less than common sense advice: "When you are innocent, act like it. If you've done nothing wrong, you should want the investigation to be as fulsome and thorough as possible" [35]. In responding to these friendly and overtly sound suggestions, Trump did exactly the opposite.

The president also surrounded himself with close associates who were not as successful in circumventing official labels of wrongdoing in the advancement of their own financial interests, all of whom he subsequently granted a pardon. For example, the arrest and indictment of former advisor and confidante, Steve Bannon, reveals that conservative ideology also allegedly served as a means for attracting support, publicity and funding for various schemes [36]. The former chief strategist at the White House made a career as an intellectual raconteur, promoting a set of populist ideas he calls "economic nationalism." The scheme he was arrested for in 2020 was hardly the "stuff of genius," but rather, a classic charity fraud [37]. Bannon and his associates started an online campaign, "We Build the Wall," supposedly to raise money to privately build portions of the wall that President Trump had long pledged to erect along the southern border with Mexico. Despite their claim that none of the donated money would be used to pay for salaries or compensation, much of it was allegedly diverted to the campaign's organizers, who used it to fund lavish lifestyles, including over one million dollars to Mr. Bannon. Another "birds-of-a feather" detail is the fact that Bannon was arrested aboard a \$35 million, 150-ft yacht owned by Chinese businessman, Guo Wengui, who himself was on the run from authorities in China where he was accused of money laundering and bribery [38].

Paul Manafort, who for a time ran Trump's presidential campaign, was serving a seven-and-a-half-year sentence for fraud before he received a presidential pardon [39]. A report issued by a Republican-controlled U.S. Senate details the nefarious activities of the former international political operative [40]. During the early 2000s Manafort earned tens of millions of dollars by orchestrating campaigns to advance Russian interests in the Ukraine and elsewhere, working closely with Russian oligarchs and intelligence officers. By 2016, Manafort was having financial difficulties stemming from his inability to be paid for his work by his Russian benefactors. In the Trump campaign he saw an opportunity to utilize his Russian connections to great personal advantage. According to the Senate report, Manafort told an associate "that working for the Trump Campaign would be good for business and a potential way for Manafort's firm to be paid for work done in Ukraine for which they were owed" [40]. Once in the position of campaign manager, Manafort began passing critical information, including polling data, to his Russian contacts who used it in their efforts to help get Trump elected. Here again, a close Trump associate was motivated perhaps not as much by political ideology as by potential financial gain.

Former national security advisor Michael Flynn is another Trump loyalist who was heavily involved with Russia and who acted in financial self-interest against the law. Pardoned by Trump, his protracted legal case saw him plead guilty to lying to federal 
investigators, and later trying to rescind his plea [41]. Attorney General Barr attempted to drop the charges, which dealt with his talks with Russians on behalf of the administration regarding the lessening of U.S. sanctions due to election meddling. Flynn also violated the law by working secretly as a well-paid consultant on behalf of the Turkish government. Well-known for leading Trump rally chants of "Lock her up!" aimed at Hillary Clinton, Flynn is yet another loyalist and close associate whose financial self-interest superseded the duties of his public office.

The list goes on with others close to the President who have been convicted for offenses related to Russian election interference and then pardoned by the person the center of their controversies who publicly dangled the reward for their silence: Roger Stone, Rick Gates, and George Papadopoulos, among others [42]. This abuse of the presidential pardon power in an attempt to extinguish investigations with direct bearing on the president's own potential criminal wrongdoing might best be described as an "in-your-face" cover up. It is nothing less than a flagrant and staggering violation of the rule of law; using power to abuse the law, in order to remain above it.

As in Watergate, it is not merely coincidental that the former president was surrounded by close associates who broke the law. A major difference in the case of Trump, is that he publicly dangled pardons to keep them from disclosing information that could incriminate him [43]. Those who complied received pardons or sentence commutations. One person who did not receive such largesse is convicted former legal counsel and "fixer" Michael Cohen, who, after being found guilty of lying to Congress, turned state's witness and testified concerning campaign violations stemming from hush money payments to a pornographic film actress, in addition to bank fraud, money laundering, and Russian connections to the Trump business enterprise that the president repeatedly lied about during the campaign [13]. Federal Judge William H. Pauley III stated in open court that Trump had directed his then-lawyer to commit a federal felony [44]. Controversial presidential pardons are nothing new, but none have been dangled in public to obstruct ongoing investigations of a sitting president.

The in-your-face corruption involved in the 2016 election was associated with Russian meddling and collusion by the campaign. The later Ukrainian extortion attempt ultimately led to impeachment but no conviction. They were major scandals of the Trump presidency that failed to scandalize.

As of this writing, two other significant events during the Trump presidency also involve questions of potential egregious criminality. The first is the COVID-19 pandemic which has cost hundreds of thousands of U.S. lives as well as historic economic devastation and related human misery. One early analysis from Columbia University indicated that as of spring, 2020, over 36,000 lives would have been spared by earlier federal intervention efforts simply to promote social distancing being urged by top scientists and public health experts [45]. Related to this estimate of unnecessary deaths, and most ironically, a series of interviews with the president by celebrated journalist Bob Woodward, who, with Carl Bernstein, was responsible for breaking the Watergate story in the Washington Post more than four decades ago, recorded him brazenly admitting that he intentionally withheld initial information regarding the seriousness and transmission of the virus [6]. Trump "defended" these actions by immediately attacking the Columbia study as a "political hit job" [46], and rebuffing Woodward's recorded confession of his passivity as a "very boring book" and, also, "just another political hit job." He claimed that he withheld information and took no action "because 
he didn't want to create a panic" [47]. Seen in a different light, commentators labeled this incredulous justification for not saving lives as an unscrupulous dereliction of duty [48-50].

The second is the series of events in the aftermath of Trump's 2020 election loss, including frivolous lawsuits based on repeated claims of thus-far non-existent systemic voter fraud. The intentional amplification and dissemination of conspiracies tied to this fraud fantasy were considered a major threat to the peaceful transition of power central to the foundation of democracy itself. Even an intensely loyalist Attorney General, William Barr, had to publicly state that no evidence existed of widespread fraud that could change the election results [51]. Christopher Krebs, director of the Cybersecurity and Infrastructure Security Agency, responsible for securing the election against domestic and foreign interference, was fired by Trump for defending the election's integrity as perhaps the highest in the nation's history against the president's continued false claims [52]. As of this writing, the only "observable systemic fraud" regarding the election appeared after the fact by continued dogged attempts to delegitimize it through unfounded claims and deranged conspiracy theories spoken through Trump-mouthpieces, such as Rudy Giuliani and Sidney Powell [53, 54]. Trump's desperate attempts to overturn the election by any means possible, emanated not only from psychological imbalances, narcissism, and authoritarian predispositions for power, but from the plain fact that once he left the White House he would be legally vulnerable; if not in Washington for federal crimes, then almost certainly in New York, where, for years, he has been under investigation for potential business and tax violations. Like campaign manager Paul Manafort, whose business dealings only came under intense scrutiny after he placed himself in the national spotlight, Trump's unexpected ascendancy to the White House justifiably brought rigorous examination to his as well.

The illusion of invulnerability [55] common to many powerful white-collar offenders, and that helped shape Trump's adult life, wore especially thin following his 2020 election loss. Requiring drastic moves to maintain the protective shield of the presidency, he propagated the outrageous and self-serving myth that if he lost the 2020 election that it was rigged. The move culminated in turning a portion of his politically potent base into a seditious mob that stormed the Capitol Building days before Joseph Biden's presidential inauguration.

\section{Playing to his base}

Despite the unchecked corruption the country witnessed in the four years of the Trump presidency, his supporters viewed his actions very differently or selectively ignored them. They genuinely appreciated his shattering of norms and status quo politics, tough immigration policies, promised Mexican border wall, anti-regulatory stance, vows to "drain the swamp" in Washington, refusals to acknowledge the Black Lives Matter movement as well as his election loss to Biden and Harris, appointing conservative judges, trying to destroy the legacy of the Obama presidency, most notably the Affordable Health Care Act, and pledging to put America first [56, 57]. Some supporters also undoubtedly feared a black and brown, rather than a white America [58]. The raucous, and radically non-progressive moves were what they voted for, evidently without regard for ethical, moral, and legal boundaries that could be violated in 
enacting them; or as Merton famously wrote in respect to social anomie, or the lack of norms, "allowing the ends to justify the means" [59]. They agreed with the president's repeated assertions after he won the 2016 election that he was a political victim, immediately suspect by his lack of experience in elected office, business background, and a cloud of Russian election meddling later proven to be favorable to him [2].

Seeing Trump as a victim of the "deep state" is extremely problematic however, if for no other reason than his own highly suspect actions. As if to intentionally encourage suspicion of his Administration's connections to the Russian government, he invited Russian diplomats inside the Oval Office where he reportedly revealed intelligence secrets [60] and celebrated the firing of the FBI Director. Trump's utterance that, "He was crazy. A real nut job," and that, "I faced great pressure because of Russia. That's taken off," was only known about through Russian media sources, as American news journalists were barred from the event [61]. Moreover, his penchant for cozying up to dictators, including Vladimir Putin who he believes more than findings from American intelligence agencies, has been characterized as "treasonous" [62]. Such prominent displays that questioned his ability to perform the duties of the office according to the law were at great odds with the conservative ideology of many supporters, yet there was no official condemnation of his behavior.

\section{The Ukraine extortion}

Another scandal occurred in 2019 when a whistleblower report indicated that he attempted to extort the leader of Ukraine by threatening to withhold military support that was previously approved by Congress. It resulted in his being the third president in American history to suffer impeachment [63].

In the Ukrainian scandal, Trump once again engaged in overt actions that violated both normative and legal standards in order to advance his personal political interests. The scandal was triggered by an incident that was first revealed by an intelligence officer who in August, 2019 filed a whistle-blower complaint that included a transcript of a phone call in which President Trump asked President Zelensky of Ukraine to investigate Trump's political rival, Joseph Biden, as well as his son, Hunter, in exchange for military assistance and a White House meeting [64]. These revelations provided congressional Democrats with the smoking gun they had long been looking for-solid evidence that Trump had broken the law in pursuit of his own self-interestand they moved quickly to begin impeachment hearings.

In the House hearings two versions of reality were presented. In the accusers' version, the telephone conversation provided unambiguous material evidence of an extortion attempt, similar to a mob shakedown, in which Trump clearly threatened to withhold U.S. military assistance if Zelensky failed to publicly announce investigations into Hunter Biden and Ukraine's efforts (not Russia's) to influence the 2016 electiona discredited theory promoted by the Trump camp [65]. In the interpretation of these events presented by Trump's defenders, the transcription of the phone conversation showed "no quid pro quo or indication of conditionality, threats, or pressure - much less evidence of bribery or extortion." To the contrary, it "reflects laughter, pleasantries, and cordiality" [66]. His Republican defenders claimed that Democrats were "trying to impeach President Trump because some unelected bureaucrats chafed at an elected 
President's 'outside the beltway' approach to diplomacy" [66]. According to this narrative, Trump's accusers were applying an out-of-context, legal framework to Trump's unorthodox, but legitimate, negotiating style. Similarly, after Trump publicly appealed to China to also investigate the Bidens, Senator Marco Rubio told the media that it was "not a real request" but insisted instead that the President was "just needling the press, knowing that you guys are going to get outraged by it" [67]. Rubio's response was part of a larger pattern of rationalizations that often followed Trump's particularly outrageous statements that he was "only kidding." Trump's supporters frequently excused his behavior by saying that he should "be taken seriously, but not literally" [68].

\section{Distraction and cover-up: Hiding in plain sight?}

Debates about the president's accountability both in office and before, will undoubtedly continue, as will the credo of "Trumpism," which embraces white nationalism and political loyalty over democracy, with unpredictable social consequences [69]. Trump has brought intense media scrutiny upon himself; through unfounded and outrageous claims, aberrant behaviors, outright denials, and documented lies. Although Trump was the president, his blatant disregard of norms and laws begs the question of whether he ever was $a$ president.

His persistent political support, despite substantial evidence uncovered through investigations of potential lawbreaking and his directly observed deviant behaviors, is a major social phenomenon in itself. The lack of effective public condemnation is at least partly due to mechanisms employed by the Administration to keep enough of that support intact, making censure impossible. One was embracing seemingly conservative values and a contrarian posture in order to enact draconian policies that created deeper political divisions and a tense public mood (e.g., promises to build a wall, arresting and terrorizing undocumented immigrants, mass deregulation, promoting law and order policies against the Black Lives Matter movement, encouraging white nationalism, and denying climate change).

Also maintaining that support were acts at odds with conservative values, and that served as major distractions from investigations into what appeared to be "in-yourface" wrongdoing. Striking up "friendships" with notorious dictators while criticizing U.S. allies, is a prime example of such a highly controversial "shiny object." Some might see this as "fresh and inventive" foreign policy, but it appeared to others as a serious threat to national security and world peace. Siding with Vladimir Putin against U.S. intelligence agencies regarding Russian election interference left the world scratching its head, and perhaps that was the intent [70]. Regardless, these bizarre issues and others like them temporarily took center stage, long enough to divert attention from scandalous behaviors of the Administration, lessening their seeming importance.

In response to information that could prove nocuous to his presidency, constant efforts to distract allowed both the time necessary to convolute such evidence through repeated attacks, and to bury it in the news cycle. Avoiding the same mistakes that foiled Nixon in Watergate, Trump succeeded in making obstruction acceptable in practice, if not in theory. He openly encouraged witnesses to defy congressional 
subpoenas during Robert Mueller's inquiry, dangled pardons and threatened retaliation for noncompliance [71]. Instead of firing the Special Counsel which was also his "legal right," he relentlessly attacked the investigation and its purported partisan nature at every opportunity on network news and social media, delegitimizing it in the eyes of many Americans. The issues were complex, ample evidence was rendered legally questionable without key witnesses to corroborate it, and the scope of the special investigation was limited by the president himself who had legal control over it. This made any potential proof of collusion or other crimes it may have uncovered impossible. The administration's concerted effort to bury the investigation also put Attorney General Barr on center stage, when he held an exculpatory press conference. He unabashedly white-washed the investigation's findings and mischaracterized its conclusions before a redacted version of the final report was released to the public. The Attorney General's grievously misleading statements compelled Mueller, a long-time friend who famously shunned the limelight, to immediately respond publicly and in writing for the record [72]. Trump's incessant interference with the investigation and the resulting real time cover-up of wrongdoing became, an in-your-face Watergate.

These strategic moves, coupled with razor-thin interpretations and misuse of the law by appointees, and narrow support in the U.S. Senate, made it impossible to hold the president legally accountable. Simultaneously, such activities themselves appealed to, and increased the loyalty of his base, which kept senators, who needed their votes, in line, and a slim margin of Senate support intact. Thus, a major means of maintaining power was by avoiding official condemnation through the use of unprecedented and constant attacks on persons, institutions, most notably law enforcement and the news media, and even facts themselves, that opposed or contradicted narratives of the Administration.

High status corporate criminals often go to great lengths to distance themselves from the crimes committed by their subordinates and to hide any incriminating evidence of their role in the decisions that authorized those criminal acts. As noted above, one of the distinctive features of Donald Trump's criminal behavior was his willingness, if not compulsiveness, to be directly and personally involved in illegal acts and to leave clear cut evidence of his involvement for others to observe. At first glance, the fact that so many of Trump's corrupt and norm-breaking acts take place in full public view-via Twitter or in transcribed phone conversations - might seem irrational; possibly a reflection of poor impulse control or narcissism. Yet, from a legal perspective there may be more method to his seeming madness. On at least two occasions the public quality of his potentially criminal acts has been raised as a legal defense that serves to mitigate his culpability. In a letter to members of Congress, Attorney General Barr cited the fact that many of Trump's actions "took place in public view" as a barrier to potential prosecution on charges of obstruction of justice [73]. What Barr meant, as legal analyst Paul Rosenzweig [74] has argued, was that in order for Trump to have committed obstruction of justice he must have had the intent to commit a crime and the knowledge that his actions constituted a crime. His failure to make any attempt to conceal his acts indicates that he lacked that awareness. When confronted with allegations of obstruction Trump could simply respond: "“If I thought it was obstruction, would I have done it on television?" Rosenzweig speculated that "a cagey criminal could game the system by obstructing in public, knowing that it weakens the prosecutor's factual case" [74]. 
The same argument was raised in response to calls for Trump's prosecution after his infamous telephone conversation with Georgia election officials in which he implored the secretary of state to "find" enough votes to declare him the winner in the state's presidential election [75]. A number of people were on the call and Trump knew or should have known that it would be made public. Another aspect of this and Trump's other potentially criminal acts that undermines the necessary element of "intent," is what one pundit referred to as "the psychopath's advantage." If Trump actually believed the lies he was telling the Georgia officials about the election then he lacked the necessary intent to defraud [76]. Harvard Law professor Jeannie Suk Gersen put the issue this way:

It's plausible Trump believes that he really won, or would have won but for fraud. The fact that Trump spoke not in secret but openly, with lawyers and his chief of staff on the call, may suggest that, in his own mind, he was demanding redress of fraud rather than pushing for it [77].

It remains to be seen whether or not this would be a successful defense should it ever be invoked in court. It appears to be based on the notion of "criminal stupidity" which, if used by common criminals caught in the act, would likely provide a futile means of claiming innocence.

\section{Criminal neutralization: Normalizing condemning the condemners}

Much of Trump's success in avoiding censure in the Russian and Ukrainian scandals entails the notion of criminal neutralization. The concept is rooted in C. Wright Mills' idea of "vocabularies of motive" which concern "anticipated consequences of questioned conduct" ([78], p. 441). Speech acts are interpreted in such a way that certain statements are taken to imply specific motives [79]. It is not merely the behavior, but the way that one reinterprets it that can minimize normative violations and cast offending acts in a different light [80]. Based on this idea, one of the most cited articles in criminology, Sykes and Matza's [81] "Techniques of Neutralization," attributes delinquency to a process by which boys justify engaging in illegal activities. They argue that delinquents do not fully embrace criminality, but instead have one foot in conventional morality and the other in delinquency. Drifting in and out of deviance, they use an array of justifications for their illegal behaviors, including denials of responsibility, victim, or injury, condemnation of condemners, and appeal to higher loyalties. These justifications and others [82] have been documented in studies of adult offenders, including white-collar criminals [83-86].

While the theory of neutralization as a "cause" of deviance is considered flawed by many sociologists, it remains a robust concept regarding the persistence of such acts, as justifications can both accompany and follow, as well as precede offensive behaviors [79]. Once engaged in deviance, such reasoning can allow it to continue [82].

Related to neutralizations are devices that Scott and Lyman [87] identify as "accounts." These are used whenever an action is subjected to evaluative inquiry, and where audiences expect the actor to make a statement to explain the behavior in question [79]. Accounts are also "situated" according to status, context, audience subgroups and other salient conditions [87]. Under circumstances of deeply divided audiences (such as those in the U.S.), there may 
be no account, or a rather weak one, as the acts may be seen as more or less reasonable by some, or the person in question may feel that it will not be honored by another group. The acts themselves become less important than the accounts, or remarks aimed at acceptability, in affecting the reactions of audiences. What is important is under what conditions such accounts are honored, and to what degree.

In the case of Trump, his well-documented narcissistic personality disorder [17] may well explain his claims that are extreme, larger than life, counter-factual and sometimes simply absurd. To his base supporters, however, such outrageous statements are revered as strong responses to partisan and unfair scrutiny, despite strong evidence to the contrary. That is, the "in-your-face" nature of both the acts in question and the accounts given are seen as part of the more admirable trait of being "a fighter" against deep-seated political and social forces out to do him in. His attacks on accusers are thus viewed as reasonable responses. Moreover, both the number of uncovered deviant and potentially illegal acts, and his repeated onslaughts on accusers in response, obfuscates and questions reality, even to the point of creating an entirely new one. This is at least partially accomplished through using the power and public reach of the presidency, amplified now more than ever before by the proliferation of social media. This state of affairs is thus normalized for both favorable and unfavorable audiences. However, when this is done intentionally (e.g., knowingly spreading lies and conspiracies), it allows: 1) continued criminality and cover up, and 2) condemning the condemners to be used as a weapon against detractors, and a shield or smokescreen to avoid accountability and sanctioning [88]. Simultaneously, these mechanisms served to help keep Trump's political base intact. Appointing loyalists to key decision-making positions, and using the law and presidency as a weapon and shield, also sanctioned further deconstruction of the state, in terms of lessening its capacity to react, resulting in further enhancement of this new hybrid form of neutralization. Resembling the means used by other major white-collar criminals to avoid accountability, there is at least one major difference; the unparalleled power of the presidency that provided the capability to normalize condemnation of condemners so that even blatant acts of corruption could be both redefined and engaged in with impunity.

The normalization of condemning the condemners is a phenomenon far more consequential than what was commonly referred to in the news media as separate calls to "investigate the investigators." It is an extraordinarily effective and unprecedented hybrid form of neutralization used by Trump to keep his foes at bay, audiences divided and political lifeline, the base, intact. The extraordinary power of the presidency allowed use of the office and the law as a weapon to engage in corruption and a shield against effective legal stigma [88, 89]. In terms of white-collar crime theory, the Trump presidency not only shows how unchecked power impacts corruption, but also provides the quintessential case study of how such power influences the trivialization of major white-collar crime [90], by relegating it to the status of a "non-issue" [91].

\section{The war on white-collar crime}

Former Senator from New York and Harvard sociologist Daniel Patrick Moynihan labelled the process whereby illegalities become more tolerable over time as "defining deviancy down" [92]. Although his analysis was confined to lower forms of offending, 
crimes of the powerful have become increasingly trivialized as well, as demonstrated in the Trump administration [93]. Among others, a prime example of such trivialization in action was Trump's abuse of the pardon power that allowed notorious white-collar felons to go free, including those whose cases were directly related to the conduct of the president himself.

These acts are part of a larger ongoing war on white-collar and corporate crime. Unlike other U.S. crime wars, such as “the war on drugs," it isn't designed to prevent or control it. Rather, it is an existential war on the very concepts and social realities of major white-collar and corporate crimes themselves. Moreover, the war's duality both disguises lawbreaking, and encourages white-collar, and likely common crimes, more generally. Proactive policing is widely considered a necessary element in the effective prevention and control of white-collar and corporate crimes. Additional resources and highly experienced personnel are required to uncover them. The severe reduction of regulatory and enforcement capacity during the Trump Administration [30], made such proactive policing much more difficult.

The 2020 election defeat weighs heavily for the former president as a lost battle in the war. Beyond usual political concerns, ideological shifts or personal vanity issues, upon leaving office Trump faces legal exposure as a private citizen in New York, if not federally as well. If he remains in the U.S. both his financial wealth and individual freedom would be at risk. This was highlighted in his "thinking out loud" during a campaign rally when he lamented, "Could you imagine if I lose? Maybe I'll have to leave the country, I don't know" [94].

In the process of protecting itself, the Trump administration engaged in efforts to delegitimize the notion of white-collar crime. Agencies were led by highly partisan appointees, many of whom engaged in such scandalous behaviors related to their jobs that they were forced to resign [30]. Slashing regulations and starving agencies inevitably leads to more violations, despite the fact that illegalities never accounted for "do not officially exist." This existential war on white-collar crime paralleled the Administration's war on COVID-19. As the president repeatedly stated publicly, if you don't test for the virus the infection rate will fall [95]. As known cases of infection continued to rise, Trump found a doctor with no public health expertise speaking on Fox News, and appointed him to lead nothing less than a disastrous effort at "herd immunity" (which Trump repeatedly referred to as "herd mentality" in a televised interview) before the availability and mass administration of an effective vaccine [96]. This unscientific, smoke-and-mirrors approach to a growing deadly pandemic didn't stop its spread in reality, just as denying resources and personnel do not prevent the proliferation of white-collar and corporate crimes, regardless of "official tallies" or final legal adjudications. Statistics on white-collar crime are already commonly referred to by experts as the mere "tip of the iceberg." Further submerging it below water where it could continue to grow unchecked was the preferred course of the Trump administration. Noteworthy are the pardons of undeserving notorious felons in the last days of his presidency, especially those given to associates who did not testify against him. One involved the perpetrator of the largest Medicare fraud case in history; a billion-dollar scheme that not only harmed patients but stole government healthcare funds [97].

Finally, and perhaps most importantly, the war exists in preventing attempts to label the actions of the Trump presidency as corrupt. This goes well beyond the particular occupant of the office, and concerns the institution of the presidency itself. There is a 
distinct and important difference between corruption within a public office to enrich its occupant, and that which involves the intentional use of the state apparatus to continue to commit crimes and to cover up past illegalities. Political scientist Theodore Lowi's [98] distinction of criminal acts which he termed "big" vs. "little" corruption characterize the actions of the current Administration. Little corruption refers to acts of individual malfeasance such as bribery, whereas big corruption involves the normalization of government deviance through political authority itself [98]. The actions involved in Watergate, as well as those of the Trump administration, entail both.

\section{Conclusion}

Four years of the Trump administration made the Watergate scandal, the worst chapter in American presidential history, appear trivial by comparison. Trump so wholly divided the electorate that it became impossible to legally adjudicate his acts as crimes while he was in office. The "in-your-face" style of offending that personal lawyer Rudy Giuliani claimed there "is nothing wrong with" when he conducted shadow foreign policy to personally benefit Trump in the Ukrainian scandal, that lying while not under oath is not illegal, and that collusion is not a crime, were normalizing hallmarks of the administration. They not only mimicked Trump's past legally dubious business practices, but, at the same time, brought America to the doorstep of a mafia state, or criminal government [99].

The victories gained in the war on white-collar have taken a massive toll in at least two ways. First, are the vast physical and financial losses ordinarily associated with major white-collar and corporate cupidity that typically come to light well after the fact. Second, enormous efforts are necessary to quickly transcend deepened political cleavages in order to restore and significantly strengthen regulatory and enforcement regimes. Through normalization of condemning the condemners, Trump exacerbated existing political differences and influenced supporters to at once ignore government crime and corruption and accept new moral narratives that flew in the face of substantial evidence of criminality. In a last desperate attempt to maintain the presidency he, members of his family, and his associates, openly incited an insurrection at the exact moment of the final legal rendering in Congress of his election loss to Joe Biden, in a failed attempt to take control of the government. The extreme political polarization he actively fostered that led to this, is described by psychologists and political scientists as "political sectarianism, or "the tendency to adopt a moralized identification with one political group and against another" [100].

In showing that white-collar crime was indeed "crime," Sutherland noted similarities and differences between white-collar criminals and professional thieves [101]. In the current case, it is illuminating to consider the almost inevitable consequences for common criminals who insistently and repeatedly condemned their accusers in the face of stark material evidence. Ultimately, they would be led out of court, in handcuffs, to face their sentence.

Evidence of systemic and significant white-collar and corporate crimes in major scandals usually appears well after immense damage comes to light. In the case of the Trump Administration both occurred in real time, with no means to stop either one. The savings and loan crisis, the 2002 corporate and accounting scandals, and the 2008 
mortgage meltdown, for example, had all been brought under control by new legislation at the time widespread damage became evident.

Over a half century ago, Gilbert Geis conducted a path-breaking study of whitecollar crime in the heavy electrical equipment industry, examining the actions and responses of corporate managers regarding price-fixing violations [102]. The topic had largely been ignored by scholars since Sutherland's formulation decades before. Its continued marginalization by scholars and policy makers has led to massively destructive financial and economic crises [103] as social inequality around the world soared to unprecedented levels. A substantial number of those victimized lost faith in democratic institutions altogether, and were willing to place their faith in authoritarian figures who promised to help them. In the past Americans have seen cults of personality as foreignbased issues that result in the absolute worst outcomes in human history, including those of all fascist regimes. This clearly is no longer the case. The war on white-collar crime plays an integral role in this ongoing threat to democracy. The Trump Administration is not the first time America was seriously confronted by the possibility of a fascist state. On at least one occasion, corporate leaders had secretly plotted to overthrow the government under the administration of President Franklin Delano Roosevelt, who they considered a socialist [104]. It is, however, the first time such a takeover was openly proffered by a U.S. president.

Trump's knowing instigation of a mass demonstration (that he publicly invited supporters to attend, promising that it was "going to be wild") that he also knew included groups prone to violence, one of whom, The Proud Boys, he directly addressed "to stand back, and stand by" in a campaign debate, led to a riot and takeover of the Capitol building the day that Congress was to certify the results of a presidential election he lost [105]. His claims of systemic election fraud were the subject of dozens of failed lawsuits in federal court regarding contested election processes, vote counting, and certification processes in multiple states, some presided over by his personally appointed judges. Trump's public calls for action on his behalf also weren't lost on others in the white power movement who openly support him, including the "Ku Klux Klan, neo-Nazi and racist skinhead groups, and large segments of the Boogaloo Boys and extralegal militias" [105]. This behavior also constitutes white-collar terrorism, which could be considered as the fostering of unlawful violence in the pursuit of political goals by persons of respectability and who hold legitimate positions of power.

As criminologists have noted, there were so many instances of potential criminality and corruption in the Trump Administration, that a new subfield of the discipline is likely to emerge that scholars can write about for years to come; "The Criminology of Donald Trump" [106]. The designation not only alludes to the amount of white-collar and state crime that took place both during his presidency and before he took office, but to other harmful acts against the environment and humanity that may not be legally defined as crime. It also refers to responses or non-responses to such offending, and their effects upon justice and respect for law, among other social institutions. The foregoing analysis has examined the trivialization of what appeared as blatant lawbreaking, and it relegation to the status of a non-issue.

The manifest link between the historic takeover of the U.S. Capitol building on January 6, 2021 and the neutralization of government lawbreaking and the war against white-collar crime, is summarily captured in a news headline [11] that places each in 
stark perspective; "Five years after the Trump era began, a physical assault on America's basic symbols of democracy feels both shocking and inevitable."

Availability of data Not applicable.

Code availability Not applicable.

Funding Not applicable.

\section{Declarations}

Conflict of interest Not applicable.

\section{References}

1. Haberman, M., \& Protess, B. (2019). Trump inaugural committee ordered to hand over documents to federal investigators. The New York Times. https:/www.nytimes.com/2019/02/04/us/politics/trumpinaugural-committee-subpoena.html.

2. Mueller III, R. S. (2019). Report on the investigation into Russian interference in the 2016 presidential election (p. 448). U.S. Department of Justice.

3. LaFraniere, S. (2020). Court throws out emoluments case brought against Trump by democrats. The New York Times. https:/www.nytimes.com/2020/02/07/us/emoluments-trump-democrats.html.

4. Cottle, M. (2020). Opinion | the self-dealing administration. The New York Times. https://www.nytimes. com/2020/10/16/opinion/trump-corruption.html.

5. Millhiser, I. (2019). The possible crimes in the Trump-Ukraine scandal, explained. Vox. https://www. vox.com/policy-and-politics/2019/9/27/20885557/criminal-laws-trump-barr-giuliani-ukraine.

6. Woodward, B. (2020). Rage (illustrated edition). Simon \& Schuster.

7. Rahn, W. (2019). 10 times trump may have obstructed justice, according to Mueller. CBS News. https:// www.cbsnews.com/news/obstruction-of-justice-10-times-trump-may-have-obstructed-justice-muellerreport/.

8. Board, T. E. (2020). Trump fundraiser to challenge voting results is the real election fraud. USA TODAY. https://www.usatoday.com/story/opinion/todaysdebate/2020/12/02/donald-trump-fundraisingchallenge-voting-results-election-fraud-editorials-debates/3782460001/.

9. Thomas, P. (2020). Trump appears to back plan to overturn election result in Congress. The Independent. https://www.independent.co.uk/news/world/americas/us-election-2020/trump-electioncongress-fraud-twitter-b1779071.html.

10. Wehner, P. (2020). Trump is losing his mind. The Atlantic. https://www.theatlantic.com/ideas/archive/ 2020/12/trump-losing-his-mind/617446/.

11. Osnos, E. (2021). Mob rule in the Capitol. The New Yorker. https://www.newyorker.com/news/ dispatch/mob-rule-in-the-capitol.

12. Bolton, J. (2020). The room where it happened: a White House memoir (illustrated edition). Simon \& Schuster.

13. Cohen, M. (2020). Disloyal: a memoir: the true story of the former personal attorney to President Donald J. Trump (illustrated edition). Skyhorse.

14. Daniels, S., \& Avenatti, M. (2018). Full disclosure (first edition). St. Martin's Press.

15. Fountain, B. (2018). Beautiful country burn again: democracy, rebellion, and revolution (illustrated edition). Ecco.

16. Hassan, S. (2019). The cult of Trump: a leading cult expert explains how the President uses mind control. Free Press.

17. Lee, B. X. (Ed.). (2019). The dangerous case of Donald Trump: 37 psychiatrists and mental health experts assess a president (updated, expanded ed. edition). Thomas Dunne Books. 
18. Nance, M., \& Reiner, R. (2018). The plot to destroy democracy: how Putin and his spies are undermining America and dismantling the west. Hachette Books.

19. Reilly, R. (2019). Commander in cheat: how golf explains Trump. Hachette Books.

20. Rucker, P., \& Leonnig, C. (2020). A very stable genius: Donald J. Trump's testing of America. Penguin Press.

21. Schmidt, M. S. (2020). Donald Trump v. The United States: inside the struggle to stop a president. Random House.

22. Souza, P. (2018). Shade: A tale of two presidents (illustrated edition). Little, Brown and Company.

23. Strzok, P. (2020). Compromised: Counterintelligence and the threat of Donald J. Trump. Houghton Mifflin Harcourt.

24. Toobin, J. (2020). True crimes and misdemeanors: the investigation of Donald Trump. Doubleday.

25. Weissmann, A. (2020). Where law ends: inside the Mueller investigation. Random House.

26. Wolff, M. (2018). Fire and fury: inside the Trump White House (first edition). Henry Holt and Co.

27. Trump, M. (2020). Too much and never enough: how my family created the world's most dangerous man. Simon \& Schuster.

28. Kessler, G., Rizzo, S., \& Kelly, M. (2020). Analysis | president trump has made more than 20,000 false or misleading claims. Washington Post. https://www.washingtonpost.com/politics/2020/07/13/ president-trump-has-made-more-than-20000-false-or-misleading-claims/.

29. Mahler, J. (2020). Can America restore the rule of law without prosecuting trump? The New York Times. https://www.nytimes.com/2020/11/17/magazine/trump-investigations-criminal-prosecutions. html.

30. Benson, M. L., Stadler, W. A., \& Pontell, H. N. (2019). Harming America: corporate crime in a context of deregulation. Victims \& Offenders, 14(8), 1063-1083. https://doi.org/10.1080/15564886.2019. 1671286.

31. Sellin, T. (1938). Culture conflict and crime. American Journal of Sociology, 44(1), 97-103 JSTOR.

32. Shover, N., \& Cullen, F. T. (2008). Studying and teaching white-collar crime: populist and patrician perspectives. Journal of Criminal Justice Education, 19(2), 155-174. https://doi.org/10.1080/ 10511250802137200.

33. Sutherland, E. H. (1945). Is "white collar crime" crime? American Sociological Review, 10(2), 132. https://doi.org/10.2307/2085628.

34. Mazzetti, M. (2019). Mueller warns of Russian sabotage and rejects Trump's 'witch hunt' claims. The New York Times. https:/www.nytimes.com/2019/07/24/us/politics/trump-mueller-testimony.html.

35. Fox News. (2018). Rep. Trey Gowdy: Mueller probe should not be shut down [Text.Article]. Fox News. https://www.foxnews.com/transcript/rep-trey-gowdy-mueller-probe-should-not-be-shut-down.

36. Feuer, A., Rashbaum, W. K., \& Haberman, M. (2020). Steve Bannon is charged with fraud in We Build the Wall campaign. The New York Times. https://www.nytimes.com/2020/08/20/nyregion/stevebannon-arrested-indicted.html.

37. Sprunt, B. (2020). Steve Bannon charged with misusing donations for Trump's border wall. NPR.Org. https:/www.npr.org/2020/08/20/904245273/steve-bannon-arrested-in-scheme-to-raise-money-fortrumps-border-wall.

38. Helderman, R. S., Dawsey, J., Shih, G., \& Zapotosky, M. (2020). How former Trump adviser Steve Bannon joined forces with a Chinese billionaire who has divided the president's allies. Washington Post. https://www.washingtonpost.com/politics/steve-bannon-guo-wengui/2020/09/13/8b43cd06-e96411ea-bc79-834454439a44_story.html.

39. Haberman, M., \& Schmidt, M. S. (2020). Trump gives clemency to more allies, including Manafort, Stone and Charles Kushner. The New York Times. https://www.nytimes.com/2020/12/23/us/politics/ trump-pardon-manafort-stone.html.

40. Mazzetti, M. (2020). G.O.P.-led senate panel details ties between 2016 Trump campaign and Russia. The New York Times. https://www.nytimes.com/2020/08/18/us/politics/senate-intelligence-russianinterference-report.html.

41. Savage, C. (2020). Trump pardons Michael Flynn, ending case his justice dept. sought to shut down. The New York Times. https:/www.nytimes.com/2020/11/25/us/politics/michael-flynn-pardon.html.

42. Talmazan, Y., Elbaum, R., \& Mhaidli, S. (2021,). Full list of Trump's last-minute pardons and commuted sentences. NBC News. https://www.nbcnews.com/politics/donald-trump/full-list-trump-slast-minute-pardons-commuted-sentences-n1254806.

43. Bennett, J. T. (2020). Trump promised pardons for staff who broke law following his orders, former official says. The Independent. https:/www.independent.co.uk/news/world/americas/us-politics/trumppardons-broke-law-illegal-miles-taylor-dhs-a9688556.html. 
44. Protess, B., Rashbaum, W. K., \& Weiser, B. (2019). Investigation into trump campaign finance violations is over, judge says. The New York Times. https:/www.nytimes.com/2019/07/17/nyregion/ michael-cohen-trump-investigation.html.

45. Glanz, J., \& Robertson, C. (2020). Lockdown delays cost at least 36,000 lives, data show. The New York Times. https://www.nytimes.com/2020/05/20/us/coronavirus-distancing-deaths.html.

46. Brewster, J. (2020). Trump attacks Columbia University for study showing inaction caused more death: "liberal, disgraceful institution." Forbes. https://www.forbes.com/sites/jackbrewster/2020/05/24/trumpattacks-columbia-university-for-study-showing-inaction-caused-more-death-liberal-disgracefulinstitution/.

47. Kessler, G. (2020). Trump says he didn't want to spark panic. But he's running on fear. Washington Post. https://www.washingtonpost.com/politics/2020/09/09/trump-says-he-didnt-want-spark-panic-hesrunning-fear/.

48. Ballhaus, R. (2020). Trump, in Bob Woodward interview, said he played down coronavirus's severity. Wall Street Journal. https://www.wsj.com/articles/trump-says-he-played-down-coronaviruss-severityin-bob-woodward-interview-11599675374.

49. Phillips, A. (2020). Was the stock market the object of Trump's 'don't create a panic' coronavirus approach? Washington Post. https:/www.washingtonpost.com/politics/2020/09/10/was-stock-marketobject-trumps-dont-create-panic-coronavirus-approach/.

50. Rupar, A. (2020). Trump's "no panic" Woodward tapes spin would be easier to buy if his campaign weren't all about panic. Vox. https:/www.vox.com/2020/9/10/21430570/trump-woodward-tapes-calmno-panic.

51. Balsamo, M. (2020). Disputing trump, Barr says no widespread election fraud. AP NEWS. https:// apnews.com/article/barr-no-widespread-election-fraud-b1f1488796c9a98c4b1a9061a6c7f49d.

52. Sanger, D. E., \& Perlroth, N. (2020). Trump fires Christopher Krebs, official who disputed election fraud claims. The New York Times. https://www.nytimes.com/2020/11/17/us/politics/trump-fireschristopher-krebs.html.

53. Karl, J., \& Steakin, W. (2021). Giuliani says he's working on Trump's impeachment defense, would argue voter fraud claims. ABC News. https://abcnews.go.com/US/giuliani-working-trumpsimpeachment-defense-argue-voter-fraud/story?id=75302032.

54. O’Brien, R. D. (2021). Trump lawyers face rebukes over election-fraud claims. Wall Street Journal. https://www.wsj.com/articles/trump-lawyers-face-rebukes-over-election-fraud-claims-11610458283.

55. Rosoff, S. M. (2007). The role of the mass media in the Enron fraud: cause or cure? In H. N. Pontell \& G. Geis (Eds.), International handbook of white-collar and corporate crime. Springer.

56. Azarlan, B. (2016). The psychology behind Donald Trump's unwavering support. Psychology Today. https:/www.psychologytoday.com/blog/mind-in-the-machine/201609/the-psychology-behind-donaldtrumps-unwavering-support.

57. Pondiscio, R. (2015). The miseducation of Donald Trump voters. US News \& World Report. https:// www.usnews.com/opinion/knowledge-bank/articles/2015-12-31/education-reform-failed-whiteworking-class-donald-trump-voters.

58. Pitts Jr., L. (2020). No, it's not the economy, stupid. Trump supporters fear a black and brown America. Miami Herald. https://www.miamiherald.com/opinion/opn-columns-blogs/leonard-pitts-jr/ article211963789.html.

59. Merton, R. K. (1938). Social structure and anomie. American Sociological Review, 3(5), 672. https:// doi.org/10.2307/2084686.

60. Lee, C. E., \& Harris, S. (2017). Trump shared intelligence secrets With Russians in Oval Office Meeting. Wall Street Journal. https:/www.wsj.com/articles/white-house-denies-trump-gave-classifiedinformation-to-russian-officials-1494890345.

61. Davis, J. H. (2017). Trump bars U.S. press, but not Russia's, at meeting with Russian officials. The New York Times. https://www.nytimes.com/2017/05/10/us/politics/trump-russia-meeting-american-reportersblocked.html.

62. Smith, D. (2018). Trump "treasonous" after siding with Putin on election meddling. The Guardian. http://www.theguardian.com/us-news/2018/jul/16/trump-finds-putin-denial-of-election-meddlingpowerful.

63. Fandos, N., \& Shear, M. D. (2019). Trump impeached for abuse of power and obstruction of Congress. The New York Times. https://www.nytimes.com/2019/12/18/us/politics/trump-impeached.html.

64. Barrett, D., Zapotosky, M., Leonnig, C. D., \& Harris, S. (2019). Trump offered Ukrainian president justice dept. help in an investigation of Biden, memo shows. Washington Post. https://www. washingtonpost.com/national-security/transcript-of-trumps-call-with-ukrainian-president-shows-him- 
offering-us-assistance-for-biden-investigation/2019/09/25/16aa36ca-df0f-11e9-8dc8-498eabc129a0_ story.html.

65. U.S. House of Representatives. (2019). H. Rept. 116-346-IMPEACHMENT OF DONALD J. TRUMP PRESIDENT OF THE UNITED STATES (2019/2020) [Legislation]. https://www.congress.gov/ congressional-report/116th-congress/house-report/346.

66. Nunes, R. D., Jordan, R. J., \& McCaul, R. M. T. (2019). Report of evidence in the democrats' impeachment inquiry in the house of representatives: republican staff report prepared for Devin Nunes. Independently published.

67. DeFede, J. (2019). “Not a real request," Florida senator Marco Rubio on Trump's China-Biden plea. https://miami.cbslocal.com/2019/10/04/florida-senator-marco-rubio-trump-china-biden-plea/.

68. Klein, E. (2021). Trump has always been a wolf in wolf's clothing. The New York Times. https://www. nytimes.com/2021/01/07/opinion/trump-capitol-protests.html.

69. Williams, P. (2020). The veterans organizing to stop Trumpism. The New Yorker. https://www. newyorker.com/news/news-desk/the-veterans-organizing-to-stop-trumpism.

70. Nussbaum, M. (2018). Trump publicly sides with Putin on election interference. POLITICO. https:// politi.co/2L4Kvan.

71. Chalfant, M., Fabian, J., \& Samuels, B. (2019). White House orders McGahn to defy House subpoena. TheHill. https://thehill.com/homenews/administration/442490-white-house-orders-mcgahn-to-defyhouse-subpoena.

72. Kahn, M. (2019). Robert Mueller's letter to Bill Barr. Lawfare. https://www.lawfareblog.com/ document-robert-muellers-letter-bill-barr.

73. Barr, W. P. (2019 24). Read Attorney General William Barr's Summary of the Mueller Report. The New York Times. https://www.nytimes.com/interactive/2019/03/24/us/politics/barr-letter-mueller-report. html, https://www.nytimes.com/interactive/2019/03/24/us/politics/barr-letter-mueller-report.html.

74. Rosenzweig, P. (2019). Unpacking the obstruction of justice mystery in the Barr letter. Lawfare. https:// www.lawfareblog.com/unpacking-obstruction-justice-mystery-barr-letter.

75. Lipton, E. (2021). Trump call to Georgia official might violate state and federal law. The New York Times. https:/www.nytimes.com/2021/01/03/us/politics/trump-call-georgia.html.

76. Goldberg, M. (2021). To defend democracy, investigate Trump. The New York Times. https://www. nytimes.com/2021/01/04/opinion/trump-georgia-call.html.

77. Gersen, J. S. (2021). A test for Congress's commitment to democracy. The New Yorker. https://www. newyorker.com/news/our-columnists/trump-and-republicans-in-congress-could-still-jeopardize-theelection.

78. Mills, C. W. (1940). Situated actions and vocabularies of motive. American Sociological Review, 5(6), 904. https://doi.org/10.2307/2084524.

79. Goode, E. (2013). Justifiable conduct: self-vindication in memoir. Temple University Press.

80. Ben-Yehuda, N. (1989). The politics and morality of deviance: moral panics, drug abuse, deviant science, and reversed stigmatization. SUNY Press.

81. Sykes, G. M., \& Matza, D. (1957). Techniques of neutralization: a theory of delinquency. American Sociological Review, 22(6), 664. https://doi.org/10.2307/2089195.

82. Maruna, S., \& Copes, H. (2005). What have we learned from five decades of neutralization research? Crime and Justice, 32, 221-320. https://doi.org/10.1086/655355.

83. Benson, M. L. (1985). Denying the guilty mind: accounting for involvement in a white-collar crime. Criminology, 23(4), 583-607. https://doi.org/10.1111/j.1745-9125.1985.tb00365.x.

84. Jesilow, P., Pontell, H. N., \& Geis, G. (1993). Prescription for profit: how doctors defraud Medicaid. University of California Press.

85. Nguyen, T. H., \& Pontell, H. N. (2010). Mortgage origination fraud and the global economic crisis: a criminological analysis. Criminology \& Public Policy, 9(3), 591-612. https://doi.org/10.1111/j.17459133.2010.00653.x.

86. Stadler, W. A., \& Benson, M. L. (2012). Revisiting the guilty mind: the neutralization of white-collar crime. Criminal Justice Review, 37(4), 494-511. https://doi.org/10.1177/0734016812465618.

87. Scott, M. B., \& Lyman, S. M. (1968). Accounts. American Sociological Review, 33(1), 46. https://doi. org/10.2307/2092239.

88. Wheeler, S., \& Rothman, M. L. (1982). The organization as weapon in white-collar crime. Michigan Law Review, 80(7), 1403. https://doi.org/10.2307/1288554.

89. Schwartz, R. D., \& Skolnick, J. H. (1962). Two studies of legal stigma. Social Problems, 10(2), 133142. https://doi.org/10.2307/799046. 
90. Pontell, H. N. (2016). Trivializing white-collar crime: theoretical, empirical, and policy implications of alternative definitions. In F. Cullen, M. Benson, \& S. Van Slyke (Eds.), The Oxford Handbook of WhiteCollar Crime (pp. 39-56). Oxford University Press.

91. Goetz, B. (1997). Organization as class bias in local law enforcement: arson-for-profit as a "nonissue." Law \& Society Review, 31(3), 557. https://doi.org/10.2307/3054046.

92. Moynihan, D. P. (1993). Defining deviancy down. The American Scholar, 62(1), 17-30 JSTOR.

93. Capehart, J. (2015). How trump is 'defining deviancy down' in presidential politics. Washington Post. https:/www.washingtonpost.com/blogs/post-partisan/wp/2015/11/23/how-trump-is-defining-deviancydown-in-presidential-politics/.

94. Chait, J. (2020). Trump says he may leave the country if he loses. Does he mean it? Intelligencer. https://nymag.com/intelligencer/2020/10/trump-may-leave-country-if-he-loses-prison-criminalprosecution.html.

95. Blake, A. (2020). Trump's continually strange comments on possibly 'overrated' coronavirus testing. Washington Post. https://www.washingtonpost.com/politics/2020/05/15/trumps-thoroughly-strangecommentary-coronavirus-testing/.

96. Abutaleb, Y., \& Dawsey, J. (2020). New trump pandemic adviser pushes controversial 'herd immunity' strategy, worrying public health officials. Washington Post. https://www.washingtonpost.com/politics/ trump-coronavirus-scott-atlas-herd-immunity/2020/08/30/925e68fe-e93b-11ea-970a-64c73a1c2392_ story.html.

97. Hiltzik, M. (2020). He was convicted in a historic healthcare fraud. Trump is letting him walk free. Los Angeles Times. https:/www.latimes.com/business/story/2020-12-29/this-trump-pardon-esformeshealthcare-fraud.

98. Lowi, T. (1981). The intelligent person's guide to political corruption. Public Affairs, 82, 1-8.

99. Kanefield, T. (2019). Trump and Giuliani's Ukraine defense pushes America closer to a mafia state. NBC News. https:/www.nbcnews.com/think/opinion/trump-giuliani-s-impeachment-defense-pushesamerica-closer-mafia-state-ncna1076261.

100. Finkel, E. J., Bail, C. A., Cikara, M., Ditto, P. H., Iyengar, S., Klar, S., Mason, L., McGrath, M. C., Nyhan, B., Rand, D. G., Skitka, L. J., Tucker, J. A., Van Bavel, J. J., Wang, C. S., \& Druckman, J. N. (2020). Political sectarianism in America. Science, 370(6516), 533-536. https://doi.org/10.1126/ science.abe1715.

101. Sutherland, E. H. (1940). White-collar criminality. American Sociological Review, 5(1), 1. https://doi. org/10.2307/2083937.

102. Geis, G. (1967). White-collar crime: the heavy electric equipment antitrust case of 1961. In M. Clinard \& R. Quinney (Eds.), Criminal behavior systems: A typology (pp. 139-150). Rinehart and Winston: Holt.

103. Tillman, R. H., Pontell, H. N., \& Black, W. K. (2017). Financial crime and crises in the era of false profits. Oxford University Press.

104. Bakan, J. (2005). The corporation: the pathological pursuit of profit and power. Free Press.

105. Belew, K. (2020). Why 'stand back and stand by' should set off alarm bells. The New York Times. https://www.nytimes.com/2020/10/02/opinion/trump-proud-boys.html.

106. Barak, G., \& Friedrichs, D. (2021). Donald Trump, his presidency, and the field of criminology. The Criminologist, 46(1), 7-10.

Publisher's note Springer Nature remains neutral with regard to jurisdictional claims in published maps and institutional affiliations. 